\title{
TWO MESOARCHAEAN TERRANES IN THE REGUIBAT SHIELD OF NW MAURITANIA.
}

R.M.KEY ${ }^{1}$, S.C.LOUGHLIN ${ }^{1}$, M.S.A. HORSTWOOD ${ }^{2}$, M GILLESPIE ${ }^{1}$, P.E.J. PITFIELD ${ }^{3}$, P.J. HENNEY ${ }^{3}$, Q.G. CROWLEY ${ }^{2}$, M. DEL RIO ${ }^{1} \&$ DARBYSHIRE, D.P.F. $^{2}$

${ }^{1}$ BGS, Murchison House, West Mains Road, Edinburgh, Scotland EH9 3LA, ${ }^{2}$ NERC Isotope Geosciences Laboratory, Keyworth, England NG12 5GG, ${ }^{3}$ BGS, Keyworth, England NG12 $5 \mathrm{GG}$.

Abstract: Two domains have previously been recognized in the Archaean Reguibat Shield of NW Mauritania, based primarily on their gross lithological differences (Rocci et al., 1991). New fieldwork has identified a major ductile shear zone (Tâçarât -Inemmaûdene Shear Zone) separating these domains and new geochronological studies show that the two domains record different Mesoarchaean histories. As such, the two domains are redefined as the Choum-Rag el Abiod Terrane and Tasiast-Tijirit Terrane. Previous isotopic studies of metamorphic lithologies of the eastern Choum-Rag el Abiod Terrane indicate a succession of crustal growth from about 3.5-3.45 Ga to between about 3.2 and 2.99 Ga. Isotopic data presented in this contribution from the Tasiast-Tijirit Terrane indicate that emplacement of major calc-alkaline plutons occurred at c.2.93 Ga after volcanism (preserved as greenstone belts) that included late felsic eruptive centres dated at c.2965 Ma. This Mesoarchaean intrusive and extrusive magmatism was confined to the Tasiast-Tijirit Terrane where it was emplaced through migmatitic orthogneisses that are the oldest lithodemic unit of the Tasiast-Tijirit Terrane. Widespread bimodal, post-tectonic magmatism in both terranes included major granitic magmatism dated at c.2730 Ma.

The N- to NNE-trending curvilinear Tâçarât -Inemmaûdene Shear Zone that separates the two terranes records late intense transpressive ductile shearing. It has a flower structure over a horizontal distance of about $70 \mathrm{~km}$ across its southern portion with unquantifiable sinistral horizontal offset, and east-directed thrusting on its eastern side where it cuts into the ChoumRag el Abiod Terrane. A new U-Pb zircon age of $2954 \pm 11$ Ma is presented for a deformed granite confined within the central part of this shear zone. A minimum age for the shearing is provided by a previously determined c. 2.73 Ga age for a post-tectonic granite that cuts across the easternmost part of the shear zone in the Choum-Rag el Abiod Terrane.

The Reguibat ${ }^{1}$ Shield (Menchikoff, 1949) forms the exposed NW part of the West African Craton that underlies much of NW Africa. This craton is a large segment of Precambrian crust $\left(\sim 4,500,000 \mathrm{~km}^{2}\right)$ stable since about $1700 \mathrm{Ma}$ and bounded on all sides by Pan African oro-

\footnotetext{
${ }^{1}$ Also spelt R'gueïbat
} 
genic belts (Cahen et al., 1984). However, much of the craton is concealed beneath a cover of various unmetamorphosed sedimentary strata and unconsolidated superficial deposits of the Sahara Desert. The Reguibat Shield refers to the northwestern part of the craton west of the Taoudeni Basin (Fig.1), whereas the southern exposed part is referred to as the Leo Shield. Dillon \& Sougy (1974) and Bessoles (1977) identified two provinces within the Reguibat Shield: a SW Province composed of rocks older than c.2000 Ma (i.e. pre-'Eburnian Cycle’) that includes the rocks described in the present paper and a central and northeastern province of Eburnian rocks (recently described by Schofield et al., 2006).

Subsequently, Rocci et al. (1991) divided the Reguibat Shield into two main parts including an 'Archaean Shield' in northern Mauritania (part of the SW Province), itself divided into an eastern Amsaga-Tiris-Ouassat domain and a western Tasiast-Lebzenia domain. Our mapping in NW Mauritania in the general area west of Atar (Key, 2003; Key \& Loughlin, 2003; Key et al., 2003; Pitfield et al., 2005), defined the geographical limits of these two domains and their contact relationship. The eastern and western domains are renamed the Choum-Rag el Abiod Terrane and Tasiast-Tijirit Terrane respectively after newly defined type areas (Pitfield et al., 2005). The redefinition of the two crustal segments as terranes is because the isotopic evidence from the present and previous studies shows that they preserve different Mesoarchaean geological histories indicative of different geotectonic settings and because they are separated by a major ductile shear zone, now named the Tâçarât -Inemmaûdene Shear Zone (TISZ). ${ }^{2}$

\section{Choum-Rag El Abiod Terrane}

Potrel et al. (1998) considered that the Amsaga region of the Reguibat Shield (the ChoumRag El Abiod Terrane) formed through a series of crustal growth events between about 3.50$3.45 \mathrm{Ga}$ until $2.73 \mathrm{Ga}$. An early event is recorded in migmatitic orthogneisses at about 3.53.45Ga (Auvray et al., 1992; Potrel, 1994; Potrel et al., 1996). Zircons from a single migmatitic gneiss were dated by the SHRIMP U-Pb method to give ages of between $3515 \pm 15 \mathrm{Ma}$ and $3422 \pm 10$ Ma with Nd model ages of about 3.64 Ga (Potrel et al., 1996). The migmatites are interlayered with mafic gneisses of possible volcanic origin, as well as with undoubted metasedimentary rocks. These include marbles and hyperaluminous gneisses (including Kfeldsparquartz-sillimanite-biotite-hercynite-garnet-gneisses and sillimanite-cordierite-garnet-gneisses). A granulite facies metamorphism was interpreted to have occurred between about 3.20 and 2.99 Ga based on SHRIMP dating of zircons from charnockites dated at $2986 \pm 8$ Ma with a whole-

\footnotetext{
${ }^{2}$ The shear zone is named after two locations where it is best exposed. There is a near-continuous section across the shear zone in the Tâçarât - (a NE-trending strip of land within the Akchar dune field to the northwest of Chami) and strongly deformed granites within the shear zone form large inselbergs at Inemmaûdene.
} 
rock Sm-Nd isochron at $3012 \pm 142 \mathrm{Ma}$ (Potrel et al., 1998) and Nd model ages of about 3.233.10 Ga (Barrère, 1967; Potrel et al., 1996). This metamorphism generated new gneissic fabrics with partial melting and emplacement of minor anatectic granites including the Ioulguend Granite (Fig. 2; Potrel et al., 1998). Later granitic magmatism dated at $2726 \pm 7$ Ma coincided with the emplacement of gabbroic intrusions dated at 2706 \pm 54 Ma and about 2740 Ma (Auvray et al., 1992; Potrel et al., 1998). Negative $\varepsilon_{\mathrm{Nd}}$ values at 2.7 Ga for one of the 'late' granites (Potrel et al., 1996 \& 1998) imply that it was, at least in part, derived from pre-existing crust. Fieldwork undertaken as part of the present study has confirmed the polyphase sequence of metamorphic and intrusive events documented by previous work.

\section{Metamorphic lithologies}

The characteristic feature of the terrane is the preponderance of high-grade (granulite facies) metamorphic rocks lacking primary (sedimentary and igneous) textures (Fig. 2). The various gneisses and charnockitic rocks described by previous workers are tectonically interlayered. Migmatitic gneisses underlie a flat regolith surface with a gravel or sand veneer and are the dominant lithology in the south. Here, other lithologies form parallel lenses, layers or sheets within the migmatitic gneisses (Key et al., 2003). Charnockitic rocks and thick, variably garnetiferous quartzofeldspathic gneiss units are the dominant northern lithologies. These lithologies are noticeably absent from the Tasiast-Tijirit Terrane. Thinner bands of other lithologies including quartzites, banded ironstones and calc-silicate rocks form strike-parallel low ridges throughout the Choum-Rag el Abiod Terrane.

The migmatitic gneisses have coarse-grained, biotite-bearing, grey tonalitic gneiss palaeosomes cut by several generations of felsic veins including invasive partial melt patches, that comprise up to $50 \%$ of the rock volume (phlebitic to stromatic migmatite textures, Fig. 3a). Petrographically, neosome phases range in composition from monzo- to syeno-granite. Garnets commonly form in clusters, and cordierite is locally present as relatively large grains in the gneissic groundmass. The whole rock chemical compositions of these migmatitic gneisses are similar to the migmatitic gneisses from the Tasiast-Tijirit Terrane. The Choum-Rag el Abiod Terrane migmatitic gneisses have $\mathrm{SiO}_{2}$ contents of $63.3-72.0 \%$ and total alkali contents of 5.7 to $9.3 \%$. Tasiast-Tijirit Terrane migmatitic gneisses have more restricted $\mathrm{SiO}_{2}$ contents (72.2-74.7\%) and also have a more restricted range of total alkali contents (6.9-8.4\%). In general, the TasiastTijirit Terrane migmatitic gneisses appear more fractionated than those of the Choum-Rag el Abiod Terrane (Pitfield et al., 2005).

Massive, variably garnetiferous quartzofeldspathic gneisses (previously referred to as 'leptynites' by Barrère, 1967) and hypersthene-bearing charnockitic gneisses can occur in stacked sequences of tabular units each up to about 40m in thickness (see also Barrère, 1967). Gneissos- 
ity in the quartzofeldspathic gneisses is defined by $\mathrm{mm}$ to $\mathrm{cm}$-thick mafic stringers and seams with parallel quartz-garnet bands up to $30 \mathrm{~cm}$ thick that may mimic a primary layering. These rocks may also carry sillimanite and hercynite spinel along with the biotite in mafic clots and aggregates.

Coarse-grained sillimanite-garnet-cordierite-Kfeldspar-gneiss bands are up to several hundreds of metres in thickness and can be traced for several kilometres along strike. Other metasedimentary rocks are uncommon and include quartz-rich lithologies (garnetiferous quartzites and quartz-schists) as well as calc-silicate rocks and banded ironstones. The quartzites appear to form 'restite' seams and pods in migmatites. Amphibolites are common as small, elongate pods parallel to gneissosity in surrounding migmatitic gneisses.

There are minor meta-igneous intrusions within the migmatitic gneisses that are only found in the Choum-Rag el Abiod Terrane. Numerous isolated small pods of dunite with criss-crossing carbonate vein networks are present along the western margin of the Terrane as well as within the sheared part of this Terrane along the eastern part of the TISZ. The pods comprise angular pieces of altered dunite (antigorite after olivine with magnetite trails) embedded in a crosscutting network of carbonate veins up to several centimetres in thickness. Individual mounds are up to about $200 \mathrm{~m}$ long and $10 \mathrm{~m}$ in height. The tectonic significance of these intrusions is not clear. Barrère (1967) mapped a series of anorthositic sheets that are also not present in the TasiastTijirit Terrane. These sheets are concordant to the regional NE-SW to N-S structural grain of the host gneisses. Individual sheets can be traced for several kilometres and are less than $100 \mathrm{~m}$ in thickness.

The southern exposed half of the Choum-Rage el Abiod Terrane is intensely sheared within the TISZ (Fig. 1). Individual lithological units (composed of all the lithologies described above) in the shears are deformed into lenses from several centimetres up to several hundred metres in length, and from less than $1 \mathrm{~cm}$ up to tens of metres in thickness. The lenses are tectonically juxtaposed in a quartz-mylonite matrix (Fig. 3b). Transposed planar fabrics are dominant, locally with a down-dip lineation.

\section{Post-TISZ c2730 Ma plutonic rocks}

Barrère (1967) mapped a large granite in the centre-east part of the Atar area that he referred to as the Touijenjert-Modreïgue Granite. He recognized a central porphyritic phase (Touijenjert Granite) surrounded by a gneissic biotite phase (Touyerma Granite). A third xenolithic phase was noted during the present fieldwork. The NNW-trending Touijenjert-Modreïgue Granite cuts across major NE-trending shears that branch off the TISZ (Figs. $1 \& 2$ ) as well as cutting obliquely across the gross layering and tectonic fabric of its metamorphic country rocks. However, the granite is itself cut by a new set of shears with zones of intense deformation (notably in 
the NW part of the intrusion). Potrel et al. (1998) obtained a SHRIMP U-Pb age of $2726 \pm 7 \mathrm{Ma}$ for the Touijenjert Granite that confirms an earlier single zircon age of $2715 \pm 11$ Ma obtained by Auvray et al. (1992).

The southernmost part of the Touijenjert-Modreïgue Granite comprises a xenolithic mediumgrained, equigranular granite. The characteristic feature of the granite is the presence of angular blocks of different types of country rocks, most notably migmatitic gneisses. The blocks are chaotically organized and vary in size from several centimetres in length to up to huge blocks that are tens of cubic metres in volume. It is suggested that the granite was emplaced into a preexisting mélange within the NE- trending shear zone.

Barrère (1967) also identified and described a major gabbro that underlies a range of large hills at Iguilid. This gabbro has an arcuate NNE-SSW shape with a strike length of about $10 \mathrm{~km}$ within the NE-trending shear zone through the middle of the Choum-Rag el Abiod Terrane (Fig. 1). The gabbro is weakly metamorphosed with foliated margins and is now referred to as the Iguilid Metagabbro. Several generations of quartzofeldspathic pegmatites cut the Choum-Rag El Abiod Terrane including late muscovite-tourmaline-garnet-beryl - bearing veins common within the Iguilid Metagabbro. Auvray et al. (1992) dated a granulitic gabbro to the south of the Iguilid body (at Guelb el Azib) at c. 2.74 Ga that led Potrel et al. (1998) to conclude that there was a second high-grade metamorphic event in this area.

\section{Tectono-thermal events}

Tectono-thermal events recognized in the Choum-Rag El Abiod Terrane are divided into (1) early (pre- TISZ) high-grade events, (2) events synchronous with the development of the TISZ zone and its NE-trending offshoot, and (3) post- TISZ events.

An early polyphase tectono-thermal history (equivalent of the Precambrian 1 event of Barrère, 1967) is recorded that produced structures subsequently flattened by shearing associated with the development of the TISZ. Gneissic fabrics are axial planar to tight to isoclinal folds of early vein phases, best seen in the migmatitic orthogneisses. The gneissosity is itself tightly folded with the development of an axial planar foliation and intrafolial, rootless folds. Ptygmatic folds and complex interference fold patterns characterize the migmatitic rocks. Larger scale folds best defined by individual lithologies such as amphibolite mimic the small-scale structures.

The early polyphase metamorphic evolution culminated in a granulite facies event that included charnockites dated at $2986 \pm 8 \mathrm{Ma}$ and terminated prior to the emplacement of post-tectonic granites and gabbroic bodies at about $2.73 \mathrm{Ga}$ (Potrel et al., 1998). Granulite facies mineral assemblages define gneissic fabrics and include various garnet-sillimanite-cordierite-Kfeldspar (hercynite spinel) assemblages in paragneisses (Fig. $3 c \& d$ ). The presence of Kfeldspar and absence of muscovite suggests that these rocks have experienced significant partial melting. Small 
pockets of symplectite seen in thin section of these paragneisses also suggest some incipient melting. The garnet-sillimanite-cordierite assemblage documented in these samples is typically stable at conditions of about $800^{\circ} \mathrm{C}$ at pressures of about $6 \mathrm{Kbars}$ (e.g. White et al., 2001) as recorded by Potrel et al. (1998) for this region. Lower PT estimates are based on microprobe data of two samples (shown in Fig 3c\&d) of garnet-sillimanite-cordierite gneiss with minor biotite, K-feldspar, plagioclase and green hercynite spinel, from the central part of the Choum-Rag El Abiod Terrane. The microprobe data were run through GPT, an Excel spreadsheet for thermobarometric calculations in metapelitic rocks (Reche \& Martinez, 1996). The key minerals are not significantly zoned and are apparently well suited to quantitative P-T estimation. GPT allows the simultaneous solution of two two-variable expressions through iteration, removing the need to assume a value for one parameter (i.e. pressure or temperature) in order to estimate the other. Iterative calculation using the calibration for garnet-biotite equilibrium of Hodges \& Spear (1982) with the garnet-plagioclase-biotite-quartz geobarometer of Hoisch (1990) produces temperature estimates of $674^{\circ} \mathrm{C}$ and $612{ }^{\circ} \mathrm{C}$, and pressure estimates of about 4.6 and 2.5 Kbars, respectively. However, iterative calculation using the calibration for garnet-cordierite equilibrium of Bhattacharya et al. (1988) with the garnet-plagioclase-biotite-quartz geobarometer of Hoisch (1990) produces slightly higher PT conditions $\left(698 \& 705^{\circ} \mathrm{C}\right.$ and $5.0 \& 3.8 \mathrm{Kbars}$ respectively). Although a substantial margin of error must be attached to the results they are consistent with mineral equilibration in a high-temperature, low-to intermediate pressure (up to $15 \mathrm{~km}$ depth) metamorphic environment. The estimated PT conditions, although lower than those recorded by Potrel et al. (1998), lie close to the reaction line for biotite + sillimanite $=$ garnet + cordierite + water (+ Kfeldspar) in the KFMASH system (Spear \& Cheney, 1989). Spear (1993) notes that all the mineral phases involved in this reaction are found to co-exist implying that the reaction is divariant. Fig. $3 \mathrm{c} \& \mathrm{~d}$ show that sillimanite growth followed cordierite as individual sillimanite laths cut across cordierite grains (and twinning in cordierite) to define (with biotite) a strong planar fabric. Garnet grains are fragmented and are also locally overgrown by sillimanite needles. Slight pinitisation of many cordierite grains indicates some retrogression.

The NE-trending shears through the southern exposed half of the Terrane are part of the Precambrian 2 event of Barrère (1967). Shear fabrics trend roughly NE-SW and dip both to the NW and SE (Fig. 4). The sheared rocks have strong planar fabrics in which all fabrics (including veins) are parallel to a new foliation. Existing folds are tightened and refolded and new structures include transposed gneissosity and ductile, westerly dipping thrusts and sub-vertical faults. Quartz-mylonites commonly infill thrust and fault planes. Individual lithological units were deformed into lenses during this event by anastomising shears (Fig. 3b). The development of these 
ductile shears pre-dated the emplacement of the Touijenjert-Modreïgue Granite as this granite truncates major NE-trending shears.

A third period of ductile shearing either occurred during emplacement of the TouijenjertModreïgue Granite, or at a later date, as the porphyritic phase of this granite is locally deformed into augen gneiss. New shears formed and individual shears within the NE-trending shear zone of event 2 were re-activated. The growth of amphibole after pyroxene, widespread growth of epidote along joint planes, and alteration of biotite to chlorite, and feldspar to sericite indicate that there was at least one regional retrogressive event after the emplacement of the late granites.

Open folding succeeded ductile shearing. Brittle deformation (equivalent of the Precambrian 3 event of Barrère, 1967) produced numerous faults and fractures with NE-SW, E-W and N-S trends. Many of these are infilled by basic dykes and secondary epidote coats joint faces. Repeated brecciation of quartz-mylonites occurred during brittle re-activation of ductile shear zones. All of these 'late' tectonic and magmatic events affected the whole of the Reguibat Shield area of NW Mauritania.

\section{Tasiast-Tijirit Terrane}

Previous geological mapping in parts of the Tasiast-Tijirit Terrane, notably by Maurin et al. (1997) identified migmatitic gneisses and major greenstone belts surrounded by younger, voluminous tonalitic/granodioritic plutons that commonly core dome-like structures. The greenstones and surrounding plutons are absent from the Choum-Rag el Abiod Terrane. Conventional $\mathrm{Rb} / \mathrm{Sr}$ whole rock and mineral ages of between 2.34 and $2.84 \mathrm{Ga}$ were previously recorded from this Terrane (Bonnici and Giraudon, 1963; Rocci et al., 1991). Chardon (1997) obtained one zircon evaporation age of c. $2.97 \mathrm{Ga}$ from migmatitic gneisses adjacent to the Chami Greenstone Belt. All the examined gneisses had Nd model ages in a restricted range of 3.05 to 3.10 Ga. A similarly determined age of c. $2.93 \mathrm{Ga}$ was obtained from a granodiorite pluton also close to the Chami Greenstone Belt and all the plutons have similar Nd model ages to the examined gneisses. Felsic volcanics from the Chami Greenstone Belt had Nd model ages from 3.05 to $3.60 \mathrm{Ga}$, suggesting involvement of older crustal material in their genesis.

Our mapping (Key, 2003; Key \& Loughlin, 2003) confirmed the earlier work and identified the oldest rocks as the variably migmatised tonalitic gneisses, one phase of which was dated by Chardon (1997) at c.2.97 Ga. These gneisses are cut by all the other 'granitic' phases and tectonically as well as unconformably underlie the greenstone belts. There are a number of small, elongate, predominantly amphibolitic units, interpreted as older greenstone belt remnants, within the tonalitic gneisses. The lithologies that make up the Tasiast-Tijirit Terrane can therefore be divided into the following three major groups (Fig. 5). 
- Migmatitic gneisses with amphibolite lenses (oldest unit) and minor gneissic granite

- Greenstone belt lithologies

- Post-greenstone belt granitoid intrusions that include major biotitetonalite/granodiorites (including plutons with abundant secondary epidote), large granites and small pegmatitic muscovite-granites that are the youngest intrusions.

The charnockites, massive quartzofeldspathic gneisses and sillimanite-garnet-cordieriteKfeldspar-gneisses that are major components of the Choum-Rag El Abiod Terrane are noticeable by their absence.

\section{Metamorphic lithologies}

There are two major textural types of early migmatitic gneiss - phlebitic and stromatic (Mehnert, 1968). Migmatitic gneisses with phlebitic textures (Fig. 6a) comprise a grey tonalitic gneiss host cut by at least 4 generations of felsic leucosome comprising intersecting felsic veins and diffuse (partial melt) zones all cut by minor metamafic dykes. The various leucosome phases comprise over $20 \%$ of the rock volume. Thick quartzofeldspathic veins define ptygmatic and convoluted folds and mafic layers form surreitic (dilatational) structures. The migmatitic gneisses preserve a complex tectono-thermal history that pre-dates deposition of the volcanosedimentary greenstone belts sequences.

Migmatites with stromatic textures (Fig. 6b) form two linear, N-S belts on either side of the western (Kreidat and Chami) greenstone belts. These gneisses have a steeply dipping N-S gneissosity on a mm- to $\mathrm{cm}$-scale accentuated by parallel white felsic veins up to about $30 \mathrm{~cm}$ in thickness and which comprise between about $10 \%$ and $50 \%$ of the rock volume. The gneissosity and veins can be followed for tens of metres across large rock pavements parallel to the mean trends of the two outcrop belts. Tight intrafolial folds within the gneissosity show that it is a transposed fabric that effectively obliterated earlier structures. The gneissosity forms an axial planar fabric to cuspate folds defined by discordant fine-grained amphibolite sheets.

The migmatitic gneisses tectonically (and locally unconformably for the Ahmeyim Greenstone Belt) underlie the various greenstone lithologies to confirm the schematic cross sections on the published Chami Sheet (Maurin et al., 1997). Larger migmatitic gneiss exposures have antiformal or dome-like aspects.

There are numerous isolated and small amphibolite pods in the migmatitic gneisses. The amphibolites are invaded by neosome phases of the surrounding migmatites and are older than the metamafic volcanic rocks of the overlying greenstone belts.

The main greenstone belts in the Tasiast-Tijirit Terrane are named as follows, from east to west (Fig. 1):

- Tijirit Greenstone Belt 
- Ahmeyim Greenstone Belt

- Sebkhet Nich Greenstone Belt in the south-east

- Kreidat Greenstone Belt in the north-centre

- Chami Greenstone Belt in the centre

- Two small greenstone belts in the west-centre referred to as the Hudeibt Agheyâne and Hadeibt Lebtheinîyé greenstone belts (collectively referred to formerly as the Lebzenia greenstone belts).

The characteristic feature of the western greenstone belts is their linear aspect parallel to the $\mathrm{N}-\mathrm{S}$ fabric of surrounding stromatic migmatitic gneisses. The eastern greenstones trend NNESSW parallel to the strike of the TISZ that defines the eastern margin of the Tasiast-Tijirit Terrane. These linear trends are clearly controlled by major tectonic events described below. All of the greenstone belts comprise interlayered mafic and ultramafic metavolcanic rocks with minor uppermost felsic metavolcanics confined to specific eruptive centres (including dated sample D on Fig. 1/ Tasiast drillcore sample in Table 1). Chemical analyses of the various greenstone belt metavolcanics (Pitfield et al., 2005) suggest that early mafic and ultramafic rocks were emplaced during initial rifting of continental crust. Siliciclastic metasedimentary rocks as well as prominent banded ironstones (Fig. 6c) are either interbanded with the mafic and ultramafic rocks (e.g. in the Ahmeyim, Hadeibt Agheyâne and Hadeibt Lebtheinîyé greenstone belts) or confined within rifts in the centres of the greenstone belts (e.g. in the Chami Greenstone Belt).

\section{Plutonic rocks}

A sequence of intrusive events is identified with most pluton-forming magmatism postdating the volcanism and associated sedimentation recorded in the greenstone belts. Pregreenstone belt plutonism is confined to small, early gneissic granites intruding into migmatites in the western part of the Tasiast-Tijirit Terrane. The planar fabric in the early granites is defined by biotite lenses ( $\sim 6 \mathrm{~cm}$ long) and a parallel quartz leaf fabric with flattened feldspars.

The commonest intrusions in the Tasiast-Tijirit Terrane are biotite-tonalites (of the Ndaouâs Suite) that form a number of large intrusions west of the Ahmeyim Greenstone Belt. The plutons cut across fabrics in the migmatitic gneisses and also intrude through folded greenstone belt successions. Small country-rock xenoliths generally comprise less than $1 \%$ of the rock volume but are locally common, notably immediately adjacent to greenstone belts where abundant metamafic volcanic xenoliths are present. The tonalites are locally foliated and gneissic (in discrete shear zones), and are cut by minor granitic vein phases.

Abundant secondary epidote as veins and as a pervasive replacement phase (of feldspar and biotite) is present in some of the tonalitic plutons. The largest of these altered plutons occurs at Gleibat el Fhoud, west of the Ahmeyim Greenstone Belt (zircon sample B on Fig. 1 = sample 
201401584 of Table 1, is from this pluton). It is a medium to coarse-grained, equigranular leucocratic rock, locally with euhedral feldspar phenocrysts (partly replaced by epidote) that are up to about $5 \mathrm{~cm}$ in length. The modal composition is close or on the tonalite-granodiorite boundary. The granodioritic to tonalitic plutons of the Ndaouâs Suite are calc-alkaline granitoids with $\mathrm{SiO}_{2}$ contents from $65.8-77.5 \%$ and $\mathrm{Na}_{2} \mathrm{O}+\mathrm{K}_{2} \mathrm{O}$ values in the interval 5.8-9.1\% that range from medium potassic through high potassic to shoshonitic intrusions (Pitfield et al., 2005).

Less common are granitic intrusions of the Bir Igueni Suite (zircon sample C on Fig. $1=$ sample 201401598 of Table 1, is from one granitic pluton) found in the centre of the Tasiast-Tijirit Terrane. These plutons have abundant rafts of migmatitic gneiss in white-grey, variably gneissic leucogranite that forms a network of criss-crossing veins. The veins form up to $50 \%$ of individual large exposures. A characteristic feature of the veins is the presence of tiny red garnets and large magnetite grains. The gneiss rafts are variably assimilated and up to tens of cubic metres in volume. There is a transitional contact between the granite and its host migmatitic gneiss with a gradual decrease in the proportion of the granite vein phase. One such granite intrudes into the north-eastern part of the Sebkhet Nich Greenstone Belt. .

A distinctive, coarse-grained to pegmatitic muscovite-granite forms a series of very small intrusions throughout the western part of the Tasiast-Tijirit Terrane. Its pegmatitic phase (that usually forms sheets and veins cutting all other lithologies of the Tasiast-Tijirit Terrane) is characterized by a range of unusual lithium, strontium and beryllium minerals as well as opaques, tourmaline, biotite and red garnet. Muscovite books in the pegmatites are up to $1 \mathrm{~m}$ in length. These micaceous granites may be coeval and comagmatic with the (late) muscovite-granites occurring in the Choum-Rag el Abiod Terrane and in the TISZ.

Tectono-thermal events

The following sequence of deformation events and associated metamorphism is preserved in the rocks of the Tasiast-Tijirit Terrane:

1. An early set of small-scale folds of gneissosity and ductile shears in the various migmatitic gneisses that pre-date the deposition of the greenstone belt sediments and volcanics. An initial high-grade event produced gneissic fabrics that are axial planar to folds defined by felsic veins. The gneissosity (as well as felsic veins and dykes) was then sheared and folded into tight to isoclinal folds. Structures include ptygmatic folds of quartzofeldspathic veins and isoclinal folds associated with ductile shears. A lack of indicator minerals precludes accurate assessments of the metamorphic grades of these early events. However, partial melting occurred as indicated by phlebitic textures (Fig. 6a). Subsequent (post-greenstone belt) tectonic events have strongly modified the original orientation of the early structures. 
2. Early tight to isoclinal folding in the greenstone belt lithologies was accompanied by the generation of a penetrative foliation and accompanying lineation (Fig. 6d). Greenschist to amphibolite facies metamorphism accompanied the folding. Ductile shearing in the eastern part of the Tasiast-Tijirit Terrane imposed a strong NNE-SSW to NE-SW tectonic grain (Fig. 4). By contrast the western part of the Terrane has a strong N-S tectonic grain imposed by shearing and transposed planar fabrics. The temporal relation between the two sets of shears is not known.

3. The emplacement of biotite-tonalite plutons modified the structure of the greenstone belts and post-dated the tectonic events recorded in the last paragraph producing open domical structures cored by the plutons (for example in the western part of the Kreidat Greenstone Belt). Discrete ductile shears locally cut the plutons, notably close to the TISZ. This period(s) of ductile deformation may have been contemporaneous with the late ductile shears seen in the Choum-Rag el Abiod Terrane. Regional retrogression is indicated by the widespread growth of epidote, chlorite and carbonate minerals. Epidote occurs along brittle fractures and replaces mafic minerals in all of the gneissic and granitic rocks. Secondary growth of chlorite and carbonate is widespread in the greenstone belts, notably in metabasalts.

4. Several generations of brittle fractures can be recognized including NE to NNE-trending fractures infilled by a sub-continental mafic dyke swarm (that extends eastwards across the TISZ and the Choum-Rag el Abiod Terrane). Late brittle fractures are locally infilled by E$\mathrm{W}$ trending, brecciated quartz reefs associated with late hydrothermal alteration. Breccias along faults in the greenstone belts locally contain clasts of chlorite schist.

\section{Tâçarât -Inemmaûdene Shear Zone (TISZ)}

Fieldwork identified a major curviplanar, NNE to NE-trending ductile shear zone approximately $70 \mathrm{~km}$ wide, that separates the Choum-Rag el Abiod and Tasiast-Tijirit terranes and also cuts into the southern exposed part of the Choum-Rag el Abiod Terrane. Anastomizing shears divide the TISZ into five major segments as follows from west to east (Fig. 1).

1. There is a foliated granite with mafic xenoliths aligned in its strong planar fabric along the western margin adjacent to the Tijirit Greenstone Belt (Fig. 7a).

2. This is bounded on its eastern side by the Tâçarât Suite of strongly foliated granites and augen granite gneisses.

3. A central zone is dominated by metamorphic rocks with transposed planar fabrics (Fig. 7b). This elongate segment has a core of steeply dipping, foliated to mylonitic, flaggy, biotite-bearing quartzofeldspathic (tonalitic) gneisses and quartz-mylonites flanked by less steeply dipping sheared lithologies including augen gneisses. The 
central gneisses have porphyroclastic textures with tiny rounded and rotated quartz grains. Amphibolite lenses in the gneisses range in length from several centimeters up to hundreds of metres. Less common are lenses of migmatitic gneiss with (transposed) stromatic textures and isoclinal folds of gneissosity and intrafolial folds within the gneissosity.

4. A wedge of foliated granitic rocks including porphyritic phases of the Aoutitilt Suite (dated sample A in Fig. $1=201401619$ of Table 1) forms an eastern core to the TISZ. The porphyritic granites contain up to $5 \%$ by volume of angular, dark mafic xenoliths up to about $30 \mathrm{~cm}$ in length and are chemically distinct from other analyzed granites from the adjoining terranes with flat chondrite-normalized REE profiles with a positive Eu anomaly (Pitfield et al., 2005). These granites are mostly strongly foliated (biotite fabric) with euhedral feldspar phenocrysts in a medium to coarsegrained groundmass of quartz, feldspar and biotite and less common hornblende. Strongly lineated augen gneisses develop where the deformation is most intense. Quartz lenses help define the gneissosity with lozenge-shaped mafic layers less than $10 \mathrm{~cm}$ in thickness in the gneissic fabric. SC' fabrics (Passchier \& Trouw, 1996) are common, with an early foliation cut by shear bands (Fig. 7c). Feldspar augen are rotated and are from one to seven $\mathrm{cm}$ in length, set in a generally coarse-grained matrix. Some augen are deformed veins rather than individual feldspar grains. Anastomizing ductile shears locally infilled by pegmatite veins are ubiquitous. Tails to augen ( $\sigma$ clasts; Fig. $7 d$ ) imply sinistral rotation in the horizontal plane on the eastern side of the 'flower structure'. A similar sinistral sense of movement is also indicated by the arrangement of individual shears and by SC' fabrics in augen gneisses (Fig. $7 \mathrm{c})$.

5. The eastern part of the TISZ, as well as a NE-trending offshoot, comprises tectonically interleaved rocks derived from the Choum-Rag el Abiod Terrane. Small-scale movement indicators (including SC' fabrics in augen granite gneiss) confirm sinistral horizontal offset along, and east-directed thrusting across, the eastern part of this transpressive, fundamental deformation zone.

An E-W cross section across the southern part of the shear zone demonstrates the presence of a 'flower structure' (Fig. 8). Further north, foliation planes dip consistently westwards across the TISZ at between about $35^{\circ}$ and $80^{\circ}$. The grade of the metamorphism that accompanied the shearing is inferred to be in the greenschist to amphibolite facies based on the presence of hornblende in sheared mafic rocks and biotite (C') fabrics in augen granite gneisses. Epidote coats joint surfaces, notably in granitic rocks. 


\section{Geochronology and isotope geochemistry}

All U-Pb ages reported in this paper are single-zircon analyses conducted by isotopedilution thermal ionization mass spectrometry at the NERC Isotope Geosciences Laboratory, UK (Table 1). Zircon separates were prepared following standard separation techniques including density separation using heavy liquids and magnetic separation to select the least magnetic, least included, non-metamict zircons. The zircons were hand picked under alcohol using a highquality binocular microscope to select the best grains for analysis, discriminating populations by virtue of morphology, size, visible cores, etc. Selected grains were rigorously abraded using the air abrasion technique of Krogh (1982) to reduce the likelihood of Pb-loss and rim phases causing discordance and mixing of age components. U- $\mathrm{Pb}$ analyses on single zircons were carried out using a ${ }^{205} \mathrm{~Pb} /{ }^{235} \mathrm{U}$ mixed spike solution following the procedures of Krogh (1973) and Parrish (1987) with modifications after Corfu \& Noble (1992). Analyses were conducted on a VG 354 multi-collector thermal ionisation mass spectrometer (TIMS) equipped with a WARP filter, axial Daly photomultiplier and Ortec ion counting detection system, or using a ThermoFinnegan Triton multi-collector TIMS instrument fitted with an axial electron multiplier. Ages and errors were determined using the Isoplot 3 macro of Ludwig (2003) using the uranium decay constants of Jaffey et al (1971) and common-Pb is corrected using a Stacey \& Kramers (1975) two-stage model lead evolution curve.

The residue remaining after ion exchange separation of $\mathrm{U}$ and $\mathrm{Pb}$, was evaporated to incipient dryness and redissolved in $2 \% \mathrm{HNO}_{3}-0.1 \mathrm{M} \mathrm{HF}$ ready for $\mathrm{Hf}$ isotope analysis by multicollector inductively coupled plasma mass spectrometry (MC-ICP-MS) following a procedure modified after Nowell \& Parrish (2000). A Thermo-Elemental Axiom MC-ICP-MS was used, coupled to a Cetac Technologies Aridus desolvating nebuliser. Corrections for $\mathrm{Lu}$ and $\mathrm{Yb}$ isobaric interferences were determined and applied following Nowell \& Parrish (2000). Data were normalised to equivalent washes of the 91500 zircon standard prepared at the same time, according to ${ }^{176} \mathrm{Hf} /{ }^{177} \mathrm{Hf}$ and ${ }^{176} \mathrm{Lu} /{ }^{177} \mathrm{Hf}$ values of 0.282284 and 0.000288 (Wiedenbeck et al., 1995) respectively. Data are presented in Table 2.

$\mathrm{Sm}$ and $\mathrm{Nd}$ concentrations were obtained by isotope dilution using a mixed ${ }^{149} \mathrm{Sm}^{-{ }^{150} \mathrm{Nd}}$ spike solution. Double filament assemblies comprising tantalum (evaporation) and rhenium (ionisation) filaments were used to run the samples, with analyses conducted on a FinniganMAT 262 multi-collector TIMS instrument. Further details of methodology can be found in Darbyshire \& Sewell (1997). Data are presented in Table 3.

\section{Data interpretation}

Despite efforts to improve the concordancy of the analyzed zircon crystals through careful hand picking and air abrasion techniques, the majority of the zircons were poor in quality which 
is reflected in the largely discordant data sets displayed below. This is not atypical of Archaean and Proterozoic terrains. At the time of writing a chemical abrasion methodology (Mattinson, 2005 ) is now employed at NIGL which helps improves concordancy of ancient and high-U zircons.

Zircons from a sample of augen granite gneiss (sample 201401619 in Table 1) within the TISZ were red-brown in colour, variably cracked and included and possessed obvious cores under an optical microscope. Care was taken to avoid visible cores and pick the least included and cracked grains for single grain U-Pb analysis. Despite this, all analyzed fractions exhibited $\mathrm{Pb}-$ loss (up to 10\%) but still formed a reasonable regression with upper intercept of $2954+/-11 \mathrm{Ma}$ (MSWD =6.1, Fig. 9A). The co-linearity of these four discordant data points argues against the variable inclusion of inherited cores. Instead, a magmatic interpretation of this age provides a maximum age for the ductile shearing within the TISZ. Since all four fractions were interpreted to be of the same age, all four wash fractions were combined for Hf isotope analysis. The data $\left(\mathrm{Hf} \mathrm{T}_{\mathrm{DM}}=3062 \pm 87 \mathrm{Ma}\right.$ and $\varepsilon \mathrm{Hf}_{\mathrm{t}}=3.1 \pm 2.4(2 \sigma)$ ) suggest derivation from a depleted mantle source with little if any contamination, contrasting with the cored nature of the zircons and the $\mathrm{Nd}$ isotope data $\left(\mathrm{Nd} \mathrm{T}_{\mathrm{DM}}=3204 \mathrm{Ma}\right.$ and $\left.\varepsilon \mathrm{Nd}=-0.7\right)$, which reflect an inherited component. This apparent decoupling of the $\mathrm{Hf}$ and $\mathrm{Nd}$ isotope data can be explained via the fact that the dominant sink for $\mathrm{Hf}$ in a melt is zircon. The refractory nature of zircon means that the Hf signature of a contaminant melt is largely 'locked' into its zircons which may not be resorbed into the host melt, especially if this melt is saturated with respect to Zr. Crystallization of new zircon will therefore reflect the $\mathrm{Hf}$ isotope composition and source of the host melt rather than the melt-contaminant mix whereas the $\mathrm{Nd}$ isotope signature will reflect the bulk-rock mixing with the contaminant. Since none of the cored zircons were selected for $\mathrm{U}-\mathrm{Pb} / \mathrm{Hf}$ analysis, the two $\mathrm{Hf}$ components can be resolved as different to the whole rock $\mathrm{Nd}$ data, and the Hf isotope data are considered to indicate the source of the 2954Ma melt.

The zircons from an epidotised tonalite of the Ndaouâs Suite (sample 201401584 in Table 1) were pink to yellow-brown in colour with a prismatic (classic tetragonal) to elongate prismatic habit. No obvious cores or inclusions were apparent. Four U-Pb TIMS data points were strongly discordant (19-31\%), forming a discordia with an upper intercept of $2912 \pm 35$ (MSWD $=10.7$, Fig. 9B). The strong discordance of these data means caution should be exercised in interpreting the upper intercept age and as such it is simply noted that the age of this sample is within error of sample 201401598 (see below). The same similarity exists in the $\mathrm{Hf}\left(\mathrm{Hf}_{\mathrm{DM}}=3075 \mathrm{Ma}, \varepsilon \mathrm{Hf}_{\mathrm{t}}\right.$

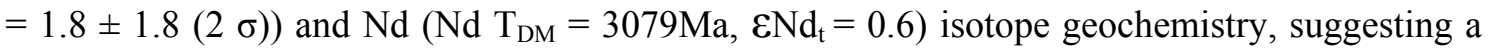
common origin for these two intrusions. 
A granite pluton from the Bir Igueni Suite of the Tasiast-Tijirit Terrane (sample 201401598 in Table 1) yielded mostly elongate prismatic grains with aspect ratio c.4:1, pink to brown-red in colour with some smaller, stubbier multi-faceted grains. Milky, high-U overgrowths were apparent on some grains; these were avoided in preference for the clearer, more crystalline pinkcoloured grains. Four data points form a discordia with an upper intercept of $2933 \pm 16 \mathrm{Ma}$ with MSWD $=12$ (Fig. 9C). The regression has a very high MSWD indicating excess scatter but this is pinned relatively near Concordia (1-2\% discordant) by two data points, lending confidence to the final upper intercept age. All four $\mathrm{Hf}$ fractions were combined to maximize the amount of $\mathrm{Hf}$ analyzed. The data ( $\left.\mathrm{Hf} \mathrm{T}_{\mathrm{DM}}=3029 \pm 70 \mathrm{Ma}, \varepsilon \mathrm{Hf}_{\mathrm{t}}=3.5 \pm 1.9(2 \sigma)\right)$ indicate a depleted mantle origin for the melt whilst the $\mathrm{Nd}$ isotope data $\left(\mathrm{Nd} \mathrm{T}_{\mathrm{DM}}=3066 \mathrm{Ma}, \varepsilon \mathrm{Nd}_{\mathrm{t}}=1.1\right)$ indicate a small amount of crustal assimilation. This is in agreement with the $\mathrm{Nd}$ model age data of Chardon (1997) for a $2.93 \mathrm{Ga}$ granodioritic pluton from the same area.

Analysis of zircons from a felsic metavolcanic rock (Tasiast drillcore in Table 1) from the (upper) Aouéoua Formation of the Chami Greenstone Belt in the Tasiast-Tijirit Terrane yielded data from only 3 small, prismatic, mauve-coloured zircon crystals after processing of more than $50 \mathrm{~kg}$ of drill core. These crystals were isolated after removing plentiful pyrite present in the sample. All three data points are discordant (Fig. 9D) with one sub-concordant. Due to the lack of co-linearity, the best estimate for the age of the rock is given by the ${ }^{207} \mathrm{~Pb} /{ }^{206} \mathrm{~Pb}$ age of the most concordant point. This represents a minimum age for the rock at c.2965Ma. The small size of the zircons provided little Hf for isotopic analysis and as such no data are presented for this sample in Table 2. The $\mathrm{Nd}$ isotope results $\left(\mathrm{Nd} \mathrm{T}_{\mathrm{DM}}=2996 \mathrm{Ma} ; \varepsilon \mathrm{Nd}_{\mathrm{t}}=2.5\right)$ suggest this volcanic rock was derived directly from a depleted mantle source with little or no crustal contamination.

Since field and petrographic evidence for the origin of this volcanic rock is ambiguous, the possibility exists that these zircons may all be inherited and that none represents the age of the rock. However, a crosscutting relationship with sample 201401598 (see below) constrains the minimum age of this rock at 2933Ma. Chardon (1997) also obtained a similar ( $\mathrm{Pb}-\mathrm{Pb}$ ) age (c. $2.97 \mathrm{Ga}$ ) and $\mathrm{Nd}$ isotope data for associated migmatitic gneisses in this area, which unconformably underlie the greenstone belts. The weight of evidence therefore suggests strongly, that the interpretation of an eruption age of c.2965Ma for this Chami Greenstone Belt volcanic is correct. This also provides an upper age limit on the greenstone belt volcanism and associated sedimentation.

\section{Discussion and conclusion}

The Reguibat Shield in NW Mauritania comprises two terranes that are lithologically different and preserve different Mesoarchaean geological histories indicative of different geotectonic 
settings (Table 4). Both terranes have migmatitic orthogneisses as their oldest components. These gneisses have previously been dated at 3.5-3.45 Ga in the Choum-Rag el Abiod Terrane, with a single zircon evaporation age of $2.97 \mathrm{Ga}$ for migmatitic gneisses of the Tasiast-Tijirit Terrane with $\mathrm{Nd}$ model ages of 3.05-3.10 Ga. However, there is evidence for a c. 3.6 Ga crustal component based on a $\mathrm{Nd}$ model age signature for the dated felsic volcanic from the Chami Greenstone Belt emplaced through migmatitic gneisses. A siliciclastic supracrustal sequence of quartzofeldspathic gneisses that includes $2.99 \mathrm{Ga}$ charnockite sheets dominates the Mesoarchaean geology of the Choum-Rag el Abiod Terrane. In contrast, a classic c. 2.93-2.97 Ga granite-greenstone belt sequence characterizes the Mesoarchaean geological record of the TasiastTijirit Terrane. In this respect the Reguibat Shield of NW Mauritania resembles the Superior province of the Canadian Shield where Archaean subprovinces and terranes characterized by granite-greenstone assemblages are tectonically juxtaposed with Archaean metasedimentary subprovinces and terranes (Card \& Ciesielski, 1986; Davis et al., 2005).

The granite-greenstone belt sequences of the Tasiast-Tijirit Terrane preserve voluminous calc-alkaline magmatism sourced from a depleted mantle with minor crustal contamination and rift-related sedimentation. The Mesoarchaean siliciclastic supracrustals of the Choum-Rag el Abiod Terrane may originally have been deposited as passive margin (accretionary prism) sediments and as such would support an interpretation that the two terranes were allochthonous to each other prior to their amalgamation along the TISZ. Granulite facies Mesoarchaean paragneisses are exposed in the Choum-Rag el Abiod Terrane whereas the exposed Mesoarchaean rocks of the Tasiast Tijirit Terrane are of greenschist facies metamorphic grade. These two assemblages represent different (lower vs mid to upper) crustal levels. However, the strongly contrasting Mesoarchaean geotectonic setting of the two terranes precludes an interpretation that they represent delamination between lower and middle crustal levels of a single terrane with the Tâçarât-Inemmaûdene Shear Zone (TISZ) as an intra-terrane structure. The measured transpressive character of the TISZ reflects post-amalgamation movement and in this respect is a typical post-collisional transpressive shear zone (Liégeois et al., 1998). Cross sections of the TISZ show an an E-W 'flower structure' across its southern part with sinistral horizontal offset and east-directed thrusting on its eastern side. Further north, shear-related fabrics dip consistently westwards to indicate that the Tasiast-Tijirit Terrane lies tectonically above the Choum-Rag el Abiod Terrane.

Widespread Neoarchaean granitic (and less common basic) magmatism throughout the Reguibat Shield followed transpressive movement along the TISZ. The c.2730 Ma age for the post-TISZ Touijenjert-Modreïgue Granite (Potrel et al., 1998) of the Choum-Rag el Abiod Ter- 
rane provides a minimum age for the shearing. A maximum age for the shearing is provided by the $2954 \pm 11$ Ma magmatic age for an Aoutitilt Suite granite from the eastern core of the TISZ.

The original size of the two terranes is not known. The present western limit of the TasiastTijirit Terrane is defined by the Pan-African (late Proterozoic-early Phanerozoic) NW Mauritanides that lie about $230 \mathrm{~km}$ west of the TISZ. Only about $50-70 \mathrm{~km}$ of the Choum-Rag el Abiod Terrane is exposed east of the TISZ before it is concealed beneath unconformably overlying strata of the Taoudeni Basin. Elsewhere on the African Plate, Archaean terranes that are up to about $800 \mathrm{~km}$ by $200 \mathrm{~km}$ in area are recognized within the Kaapvaal Craton (Eglington \& Armstrong, 2004; de Wit \& Tinker, 2004 and references therein).

\section{Acknowledgements}

The work described in this paper formed part of the World Bank-funded PRISM Project of the Government of Mauritania and the authors wish to thank Mr. Samory, the Project Coordinator for all his logistical support. Several referees are thanked for their detailed comments on earlier drafts of this paper. This paper is published by permission of the Executive Director, British Geological Survey, Natural Environmental Research Council (NERC) and is NIGL publication no. 670 .

\section{References}

AUVRAY, B., PEUCAT, J.J., POTREL, A., BURG, J.P., DARS, R. \& LO, K. 1992. Donnees geochronologiques nouvelles sur l'Archeen de l'Amsaga (dorsale Reguibat, Mauritanie)Comptes Rendus de l'Academie des Sciences, Paris, 315, 63-70.

BARRÈRE, J. 1967. Le groupe precambrien de l'Amsaga entre Atar et Akjoujt (Mauritanie). Etude d'un métamorphisme profond et de ses relations avec la migmatisation: Mémoire du BRGM, 42, 278p.

BESSOLES, B. 1977. Géologie de l'Afrique. Le craton Ouest Africain: Mémoire du BRGM , v. $88,404 p$.

BHATTACHARYA, A., MAZUMDAR, A.C., \& SEN, A.C. 1988. Fe-Mg mixing in cordierite; constraints from natural data and implications for cordierite-garnet geothermometry in granulites: American Mineralogist, 73, 338-344.

BLICHERT-TOFT, J. \& ALBARÈDE, F. 1997. The Lu-Hf isotope geochemistry of chondrites and the evolution of the mantle-crust system. Earth and Planetary Science Letters, 148, pp.243258

BONNICI, J.P. \& GIRAUDON, R., 1963, Le groupe du Tasiast, nouvelle unité lithostratigraphique du socle antécambrien de la Mauritanie occidentale: Bulletin de la Société Géologique de France, 5, 1118-1123. 
CAHEN, L., SNELLING, N.J., DELHAL, J., VAIL, J.R., BONHOMME, M. \&LEDENT, D. 1984. The geochronology and evolution of Africa. Clarendon Press, Oxford. 512p.

CARD, K.D. \& CIESIELSKI, A. 1986. DNAG\#1 Subdivisions of the Superior province of the Canadian shield. Geosciences Canada, 13, 5-13.

CHARDON, D. 1997. Les déformations continentales archéennes. Exemples naturels et modèlisation thermomécanique. Mémoires de Géosciences Rennes, 76, 257p.

CORFU, F. \& NOBLE, S. R. 1992. Genesis of the southern Abitibi greenstone belt, Superior Province, Canada: Evidence from zircon Hf-isotope analyses using a single filament technique. Geochimica et Cosmochimica Acta, 56, 2081-2097.

DARBYSHIRE, D.P.F. \& SEWELL, R.J. 1997. Nd and Sr isotope geochemistry of plutonic rocks from Hong Kong: implications for granite petrogenesis, regional structure and crustal evolution. Chemical Geology, 143, 81-93.

DAVIS, D.W., AMELIN, Y., NOWELL, G.M. \& PARRISH, R.R. 2005. Hf isotopes in zircon from the western Superior province, Canada: Implications for Archean crustal development and evolution of the depleted mantle reservoir. Precambrian Research, $140,132-156$.

DEPAOLO, D.J., LINN, A.M. \& SCHUBERT, G. 1991. The Continental crustal age distribution: methods of determining mantle separation ages from $\mathrm{Sm}-\mathrm{Nd}$ isotopic data and application to the southwestern United States. Journal of Geophysical Research (Solid Earth and Planets), 96, B2, 2071-2088

DE WIT, M. \& TINKER, J. 2004. Crustal structures across the central Kaapvaal Craton from deep-seismic reflection data. South African Journal of geology, 107, 185-206.

DILLON, W.P. \& SOUGY, J.M.A. 1974. Geology of west Africa and Canary and Cape Verde Islands, in Nairn, A.E.M., and Stehl, F.G., eds., The ocean basins and margins, Vol. 2, The North Atlantic: chapter 10, 315-390.Plenum Press, New York-London.

EGLINGTON, B.M. \& ARMSTRONG, R.A. 2004. The Kaapvaal Craton and adjacent orogens, southern Africa: a geochronological database and overview of the geological development of the craton. South African Journal of Geology, 107, 13-32.

GRIFFIN, W.L., BELOUSOVA, E.A., SHEE, S.R., PEARSON, N.J. \& O’REILLY, S.Y. 2004. Archaean crustal evolution in the northern Yilgarn Craton: $\mathrm{U}-\mathrm{Pb}$ and $\mathrm{Hf}$ isotope evidence from detrital zircons. Precambrian Research, 131, 231-282.

HODGES, K.V. \& SPEAR, F.S. 1982, Geothermometry, geobarometry and the $\mathrm{Al}_{2} \mathrm{SiO}_{5}$ triple point at Mt. Moosilake, New Hampshire: American Mineralogist, 67, 1118-1134. 
HOISCH, T.D., 1990, Empirical calibration of six geobarometers for the mineral assemblage quartz+muscovite+biotite+plagioclase+garnet: Contributions to Mineralogy \& Petrology, 104, 225-234.

JAFFEY, A. H., FLYNN, K. F., GLENDENIN, L. E., BENTLEY, W. C. \& ESSLING, A. M. 1971. Precision measurements of half-lives and specific activities of ${ }^{235} U$ and ${ }^{238} U$ : Physics Reviews, C4, 1889-1906.

KEY, R.M. 2003. 1:200,000 geological map of the Chami Sheet (2015). Islamic Republic of Mauritania.

KEY, R.M. \& LOUGHLIN, S.C. 2003. 1:200,000 geological map of the Ahmeyim Sheet (2014). Islamic Republic of Mauritania.

KEY, R.M., LOUGHLIN, S.C. \& WATERS, C.N. 2003. 1:200,000 geological map of the Atar Sheet (2013). Islamic Republic of Mauritania.

KROGH, T. E. 1973. A low contamination method for the hydrothermal decomposition of zircon and extraction of $\mathrm{U}$ and $\mathrm{Pb}$ for isotopic age determinations: Geochimica et Cosmochimica Acta, 37, 485-94.

KROGH, T. E. 1982. Improved accuracy of U-Pb zircon ages by the creation of more concordant systems using an air-abrasion technique: Geochimica et Cosmochimica Acta, 46, 637-649. LIÉGEOIS, J-P., NAVEZ, J., HERTOGEN, J. \& BLACK, R. 1998. Contrasting origin of postcollisional high-K calc-alkaline and shoshonitic versus alkaline and peralkaline granitoids. The use of sliding normalization: Lithos, 45, 1-28.

LUDWIG, K. R. 1980. Calculation of uncertainties of U-Pb isotope data: Earth and Planetary Science Letters, 46, 212-220.

LUDWIG, K. R.. 2003. User's manual for Isoplot 3.00: a geochronological toolkit for Microsoft Excel. Berkeley Geochronology Center Special Publication.

MATTINSON, J.M. 2005. Zircon U-Pb chemical-abrasion (CA-TIMS) method: combined annealing and multi-step dissolution. Chemical Geology, 220, 47-66

MAURIN, G., BRONNER, G., LE GOFF, E. \& CHARDON, D. 1997. Notice explicative de la carte géologique au 1/200,000 de la feuille Chami (Mauritanie) - Prospection aurifère dans le Tasiast-Tijirit. Rapport, BRGM, No 2459, 32p.

MENCHIKOFF, N. 1949. Quelques traits de l'histoire géologique du Sahara occidental. Livre jubilaire Charles Jacob, Annales Hêbat et Haug, 7, 303-325.

MEHNERT, K.R. 1968. Migmatites and the origin of granitic rocks. Elsevier, Amsterdam.

NOBLE, S. R., TUCKER, R. D. \& PHARAOH, T. C. 1993. Lower Palaeozoic and Precambrian igneous rocks from eastern England, and their bearing on late Ordovician closure of the Tornquist Sea: constraints from U-Pb and Nd isotopes: Geological Magazine, 130, 835-846. 
NOWELL, G.M. \& PARRISH, R.R. 2000. Simultaneous acquisition of isotope compositions and parent/daughter ratios by non-isotope dilution mode plasma ionisation multi-collector mass spectrometry (PIMMS). In: Holland \& Tanner (eds) Plasma source mass spectrometry: The new Millennium. Royal Society of Chemistry, Special Publication No.267.

PARRISH, R. R. 1987. An improved micro-capsule for zircon dissolution in U-Pb geochronology: Chemical Geology (Isotope Geoscience Section), 66, 99-102

PARSON, L.M., MURTON, B.J. \& BROWNING, P. 1992. Ophiolites and their Modern Oceanic Analogues: Special Publication Geological Society London, 60, 330p.

PASSCHIER, C.W. \& TROUW, R.A.J. 1996. Microtectonics. Springer-Verlag, Berlin Heidelberg. 289 p.

PITFIELD, P.E.J., KEY, R.M., WATERS, C.N., HAWKINS, M.P.H., SCHOFIELD, D.I., LOUGHLIN, S.C. \& BARNES, R.P. 2005. Notice explicative des cartes géologiques et gîtologiques au 1/200,000 et 1/500,000 du Sud de la Mauritanie. DMG, Ministère des Mines et de l'Industrie, Nouakchott, Mauritanie.

POTREL, A. 1994. Evolution tectono-métamorphique d'un segment de croûte continentale archéenne. Exemple de l'Amsaga (R.I. Mauritanie), Dorsale Réguibat (Craton Ouest Africain). Mémoire de Géosciences Rennes, 56, 400p.

POTREL A., PEUCAT, J.J., FANNING, C.M., AUVRAY, B., BURG, J.P. \& CARUBA, C. 1996. 3.5Ga old terranes in the West African Craton, Mauritania: Journal Geological Society London, 153, 507-510.

POTREL A., PEUCAT, J.J. \& FANNING, C.M. 1998. Archean crustal evolution of the West African Craton; example of the Amsaga area (Reguibat Rise); U-Pb and Sm-Nd evidence for crustal growth and recycling: Precambrian Research, 90, 107-117.

RECHE, J. \& MARTINEZ, F.J. 1996. GPT; an EXCEL spreadsheet for thermobarometric calculations in metapelitic rocks: Computers and Geosciences, 22, 775-784.

ROCCI, G., BRONNER, G. \& DESCHAMPS, M. 1991. Crystalline Basement of the West African Craton, in Dallmeyer, R.D. and Lécorché J.P., eds., The West African orogens and circum-Atlantic correlatives. 31-61. Springer-Verlag.

SCHOFIELD, D., HORSTWOOD. M.S.A., PITFIELD, P.E.J., CROWLEY, Q.G., WILKINSON, A.F. \& SIDATY, H.C.O. 2006. Timing and kinematics of Eburnean tectonics in the central Reguibat Shield, Mauritania. Journal Geological Society London, 163, 549-560.

SPEAR, F.S. 1993. Metamorphic phase equilibria and pressure-temperature-time paths. Mineralogical Society of America. 799p.

SPEAR, F.S. \& CHENEY, J.T. 1989. A petrogenetic grid for pelitic schists in the system $\mathrm{SiO}_{2}-$ $\mathrm{Al}_{2} \mathrm{O}_{3}-\mathrm{FeO}-\mathrm{MgO}-\mathrm{K}_{2} \mathrm{O}-\mathrm{H}_{2} \mathrm{O}$. Contributions, Mineralogy \& Petrology, 101, 149-164. 
STACEY, J.S. \& KRAMERS, J.D. 1975. Approximation of terrestrial led isotope evolution by a two-stage model. Earth and Planetary Science Letters, 26, 207-221. WEIDENBECK, M., ALLÉ, P., CORFU, F., GRIFFIN, W.L., MEIER, M. OBERLI, F., VON QUADT, A., RODDICK, J.C. \& SPIEGEL, W. 1995. Three Natural zircons standards for U-Th-Pb, Lu-Hf, trace element and REE analyses. Geostandards Newsletter, $19,1,1-23$.

WHITE, R.W., POWELL, R. \& HOLLAND, T.J.B. 2001. Calculation of partial melting equilibria in the system $\mathrm{Na}_{2} \mathrm{O}-\mathrm{CaO}-\mathrm{K}_{2} \mathrm{O}-\mathrm{FeO}-\mathrm{MgO}-\mathrm{Al}_{2} \mathrm{O}_{3}-\mathrm{SiO}_{2}-\mathrm{H}_{2} \mathrm{O}$ (NCKFMASH). Journal of Metamorphic Geology, 19, 139-153. 


\section{Figure captions:}

1. The major geological features of the study area. The granite in the Choum Rag el Abiod column is the Touijenjert Granite. Circled letters show the locations of the dated samples, as follows: A. Augen granite gneiss, sample 201401619 B. Epidote-tonalite of the Gleibat el Fhoud Suite, sample 201401584 C. Bir Igueni Granite, sample 201401598 D. Felsic metavolcanic from the Chami Greenstone Belt, sample 201500738.

2. A simplified geological map of the Choum-Rag el Abiod Terrane showing the distribution of the main lithological components. The TISZ shear zones are extrapolated under the Akchâr Dune Field.

3. (a) Blocks of massive migmatitic tonalite gneisses in the southern part of the ChoumRag el Abiod Terrane away from the major shear zones at W13.48280 N20.34860. Note the small basalt dyke to the right of the men. BGS photo P513290. (b) Lenticular fabric typical of shear zones in the Choum-Rag el Abiod Terrane at W13.38115 N20.24778. BGS photo P513193. (c \& d) Polished (thick) section images (crossed polarizers and plane polarized light, respectively) of biotite-quartz-Kfeldspar-garnet-sillimanitecordierite gneiss (sample 20131250), in which trails and elongate crystals of garnet, sillimanite and biotite define a strong planar fabric. Field of view $=3 \mathrm{~mm}$. BGS photos P1010168 and P1010169 respectively.

4. Lower hemisphere equal area stereonet plots of poles to foliation and gneissosity for the Choum-Rag el Abiod Terrane and eastern and western domains of the Tasiast-Tijirit Terrane.

5. The distribution of igneous rocks within the Tasiast-Tijirit Terrane and adjoining parts of the TISZ.

6. (a) Migmatitic tonalite gneiss cut by ptygmatically folded granitic veins in the TasiastTijirit Terrane at W14.94257 N20.99558. BGS photo P513260. (b) Stromatic or straight gneisses in the western part of the Tasiast-Tijirit Terrane at W15.61730 N21.00081. BGS photo P522082. (c) Isoclinal folds, locally with sheared-out limbs in BIF of the Hadeibt Lebtheinîyé Greenstone Belt at W15.86750 N20.95300. BGS photo P521983. (d) Float of L-tectonites (talc-phyllites) with characteristic arrowhead shapes from the 
southern part of the Chami Greenstone Belt at W15.58889 N20.49333. BGS photo P521989.

7. (a) Xenolithic granite with mafic xenoliths aligned in the foliation. BGS photo P513309. (b). Transposed gneissic fabrics in migmatitic gneisses in the western part of the TISC. BGS photo P513321. (c) SC' fabric in augen granite gneiss in the northern part of the shear zone at W13.56990 N21.19645. BGS photo P522133 (d) Close-up of 7c to show $\sigma$ clasts of Kfeldspar indicating sinistral offset.

8. Cross-section across the southern part of the Tâçarât -Inemmaûdene Shear Zone.

9. A.U-Pb (TIMS) Concordia plot for sample 201401619 (augen granite gneiss).

B. U-Pb (TIMS) Concordia plot for sample 201401584 (tonalite).

C. U-Pb (TIMS) Concordia plot for sample 201401598 (granite).

D. U-Pb (TIMS) Concordia plot for sample 201500738 (felsic metavolcanic).

\section{Table caption:}

1. U-Pb zircon data for the dated samples.

2. MC-ICP-MS Lu-Hf isotope geochemistry

3. ID-TIMS Nd isotope geochemistry

4. A summary of the Archaean histories of the Choum-Rag el Abiod and TasiastTijirit terranes. 